\title{
State and Church Sponsored Printing by Jan Januszowski and His Drukarnia Łazarzowa (Officina Lazari) in Krakow
}

\author{
Justyna Kiliańczyk-Zięba
}

One of most prominent printing-houses in Krakow, the capital of print in early modern Poland-Lihuania, was an enterprise best known by its Latin name: Officina Lazari. The ownership of the Drukarnia Łazarzowa, as it was called in Polish, stayed within a single family for almost a century, making it one of the most stable printing houses in the region. Despite its prominence, relatively little is known about Drukarnia Łazarzowa's operations. The business history of the workshop, as well as the owners efforts to make the press viable thanks to the support of powerful individuals is scarcely studied. This article seeks to add to our knowledge about the relationship between Officina Lazari and contemporary authorities, both lay and ecclesiastical. It analyses the state and church-sponsored printing produced by Drukarnia Łazarzowa between 1577 and 1587 , arguing that during that period its owner, Jan Januszowski (15501613) was able to secure the workshop's position by profiting from his connections with state and church authorities.

Beginning with a brief introduction on the dynamics of book production in sixteenth-century Krakow, the article will focus on analysing the initial decade of Januszowski's printing activity. In order to understand both Janusowski's ambitions and his connections to state authorities and church prelates, I will first discuss his background and education. Next, I will give examples of books Januszowski produced thanks to the patronage of highly placed individuals. Though the printer also received royal commissions, I will concentrate on the church patronage that the Drukarnia Łazarzowa obtained. As we shall see, Januszowski devoted huge efforts to receive commissions for printing post-Tridentine liturgical books, resulting in the appearance of the most illuminating and best-documented example: a monumental missal financed by the bishop of Warmia. The wealth of archival evidence about the realisation of this particular edition makes it possible to reconstruct the dynamics of a production process for a massive volume, whose printing was commissioned and paid for by a potent prelate. 


\section{Krakow, the Book Centre of Poland-Lithuania}

By the 145os, when printing began in Europe, Krakow was an established place of power, learning and trade. It was a major urban centre in the largely rural region: the seat of secular and church authorities and (with the university founded in 1364) a city linked by a network of intellectual connections with other European kingdoms. Well situated at a junction of trade routes, it also remained an important economic hub. As such, Krakow constituted a vibrant market for books: the city was a natural distribution point for books imported from the printing dominions of Western Europe, and it developed its position as a centre of book production simultaneously. ${ }^{1}$ The first presses operated in Krakow as early as 1473, and in the sixteenth century, the city became the principal printing centre in its region of Europe, dominating other publishing towns, which were more modest than the capital of the multinational, multi-ethnic and multilingual state of Poland-Lithuania. Already in the fifteenth century, printers in Krakow produced books in Latin and in Old Church Slavonic (printing the earliest books in Cyrillic script). In the sixteenth century they started to print in Polish and other European vernaculars (producing the first books in Hungarian in the world), as well as in Greek and in Hebrew. Surviving material documents the broad range in the output of the Krakow presses, and the extent of local printers' experience with books addressed to different audiences. ${ }^{2}$

During the sixteenth century, more than twenty printing offices were active in the city. Among these was an enterprise operating in Gołębia Street - in platea Columbarum. The ownership of the firm, established ca. 1517 by Hieronim

1 Janina Bieniarzówna and Jan Małecki, Kraków w wiekach XVI-XVIII (Krakow: Wydawnictwo Literackie, 1984); Maria Bogucka and Henryk Samsonowicz, Dzieje miast i mieszczaństwa w Polsce przedrozbiorowej (Wrocław: Ossolineum, 1986), pp. 329-392, pp. 489-5o8; Jan Małecki, 'Rola Krakowa w handlu Europy Środkowej w XVI i XVII w.', Zeszyty Naukowe Akademii Ekonomicznej w Krakowie, 70 (1974), pp. 174-175; Jan Pirożyński, 'Der Buchhandel in Polen in der Renaissance-Zeit', in Hubert G. Göpfert etc. (eds.), Beiträge zur Geschichte des Buchwesens im konfessionellen Zeitalter (Wiesbaden: Harrassowitz, 1985), pp. 267-294; Jan Pirożyński, 'Zagadnienie eksportu polskiej książki na zachód Europy w XVI wieku w świetle ówczesnych targowych katalogów i bibliografii', Sobótka, 3-4 (1982), pp. 249-258; Monika Jaglarz, Księgarstwo krakowskie XVI wieku (Krakow: Towarzystwo Miłośników Historii i Zabytków Krakowa, 2004); Renata Żurkowa, Ksiegarstwo krakowskie w pierwszej połowie XVII wieku (Krakow: Towarzystwo Miłośników Historii i Zabytków Krakowa, 1992).

2 Alodia Kawecka-Gryczowa, 'Kraków', in Alodia Kawecka-Gryczowa (ed.), Drukarze dawnej Polski, vol. 1: Małopolska, part 1: Od XV do XVI wieku (Wrocław: Ossolineum, 1983) (henceforth quoted as Drukarze 1, 1), pp. 105-115. 
Wietor, remained within the inheritance of a single family: Wietor's widowed wife Barbara, then her new husband Łazarz Andrysowic, and finally Jan Januszowski, who was the son of Barbara and Łazarz. In the seventeenth century, the printing office was to be inherited by Januszowski's sons' (who never became seriously interested in printing books themselves) and then was finally sold. Managed by Jan Januszowski from 1577 onwards, Drukarnia Łazarzowa became one of the most prominent printing houses in Krakow both in terms of the number of editions and quality of printing. ${ }^{3}$ Januszowski's ambitions to produce beautiful books and to print significant texts were apparent as early as the first decade of his activity as a printer (1577-1587) - the years of King Stefan Batory's (Báthory István) reign over the Polish-Lithuanian Commonwealth (1576-1586) - right after the young master-printer inherited Drukarnia Łazarzowa from his father. To understand Januszowski's position as he started his career as a printer, it is important to note two things. First, that a vital part of Januszowski's inheritance was an extensive social network built by his predecessors. Second, that Januszowski started the business with an upbringing that was rather unusual for the son of a craftsman.

Januszowski inherited a printing house with long-standing traditions, one that had already been active for 6o years, and that was an important site on the map of sixteenth-century Krakow. ${ }^{4}$ By the time of Januszowski's management, its previous owners had produced over goo editions, which survive to the present day (while a great number must have perished over the intervening five centuries). They had developed various relations with the Krakow University's authorities and scholars, with local intellectuals, and with the town elite as well as with the Church dignitaries and state officials. These connections undoubtedly helped the young printer to garner the support needed for his own publishing ventures. We know that Januszowski was recommended to

3 Drukarnia Łazarzowa managed by Jan Januszowski printed over 400 known editions in almost 9,0oo sheets. See Alodia Kawecka-Gryczowa, 'Januszowski Jan', in Drukarze 1, 1, p. 69-99; Renata Żurkowa, 'Januszowski Jan', in Jan Pirożyński (ed.), Drukarze dawnej Polski, vol. 1: Matopolska, part 2: Wiek XVII-XVIII, vol. 1 (Krakow: Polska Akademia Umiejętności, 200o), pp. 250-257; Renata Żurkowa, Łazarzowa Drukarnia, in J. Pirożyński (ed.) Drukarze dawnej Polski, vol.1: Matopolska, part 2: Wiek XVII-XVIII, vol. 2 (Krakow: Polska Akademia Umiejętności, 2000), pp. 411-412.

4 Justyna Kiliańczyk-Zięba, 'In Platea Columbarum. The Printing House of Hieronim Wietor, Łazarz Andrysowic and Jan Januszowski in Renaissance Krakow', Publishing History, 67 (2010), pp. 5-37. For details concerning the production of Wietor, Wietorowa and Andrysowic see as well: Anna Mańkowska and Alodia Kawecka-Gryczowa, 'Wietor Hieronim', in Drukarze 1, 1, pp. 325-352; Alodia Kawecka-Gryczowa and Anna Mańkowska, 'Wietorowa Barbara', in Drukarze 1, 1, pp. 352-357; Alodia Kawecka-Gryczowa and Anna Mańkowska, 'Andrysowic Łazarz', in Drukarze 1, 1, pp. 124-137. 
prospective patrons as a descendant of outstanding printers who had served the predecessors of potential backers as if these relationships could be heritable, and he himself used his lineage to obtain new commissions. ${ }^{5}$

Januszowski was not just a craftsman's son brought up in the workshop of his father. As a teenager, Januszowski had received instruction at the court of Emperor Maximilian II in Vienna and at Krakow University. At the beginning of 1570, he worked as a scribe writing letters in the private chancellery of Zygmunt August (Sigismund Augustus the Jagiellon, 1520-1572). ${ }^{6}$ Joining the Jagiellonian court meant that the printer's son encountered intellectuals and statesmen either employed by the chancellery or working for the monarch from a very early age. After Sigismund Augustus died in 1572, Januszowski set off to study law in Padua, supported with both the money he inherited from his mother, and a grant from Mikołaj Firlej, an influential nobleman, who would later become the voivode of Krakow. Januszowski returned to Krakow just before the newly elected King, Stefan Batory, was crowned in 1575. Upon his return, he soon re-joined the royal chancellery and remained in service, close to the king and state affairs, until his father died in 1577. Both his university education and the time he spent at court certainly broadened the craftsman's son's horizons, and stimulated intellectual ambitions of a prospective printer, who was also a prolific writer and translator. ${ }^{7}$ Importantly, Januszowski established a network of contacts during his formative years. When he left the royal court in 1577 for the printing shop, he could rely on these connections to obtain commissions and privileges and, as a result, to develop the position of his enterprise.

5 Letter by Tomasz Płaza to Marcin Kromer on 6 November 1582, Archiwum Archidiecezji Warmińskiej w Olsztynie (further as AAWO), call no AB D 35, f. 52v; Letter by Jan Januszowski to Bishop Marcin Kromer on 19 November 1585, AAWO, call no AK, Ab 5, f. 189-189v.

6 On royal chancellery and court in Poland see: Marek Ferenc, Dwór Zygmunta Augusta. Organizacja $i$ ludzie, (Krakow: Towarzystwo Wydawnicze Historia Iagellonica, 1998); Mirosław Korolko, Seminarium Rzeczypospolitej Królestawa Polskiego. Humaniści w kancelarii królewskiej Zygmunta Augusta (Warsaw: Wiedza Powszechna, 1991); Leszek Kieniewicz, 'Sekretariat Stefana Batorego. Zbiorowość i kariery królewskich sekretarzy', in Anna Izydorczyk and Andrzej Wyczański (eds.) Spoteczeństwo staropolskie, vol. 4 (Warsaw: Państwowe Wydawnictwo Naukowe, 1986), pp. 33-61; Waldemar Chorążyczewski, 'Początki kancelarii pokojowej za Jagiellonów', in Waldemar Chorążyczewski and Wojciech Krawczuk (eds.), Polska kancelaria królewska między wtadza a spoteczeństwem (Warsaw: Wydawnictwo DiG, 2008), pp. 33-46.

7 About Januszowski's formation and his activity as a writer and a translator see Justyna Kiliańczyk-Zięba, Czionką i piórem. Jan Januszowski w roli pisarza i ttumacza (Krakow: Universitas, 2007). On other printer-intellectuals see Elizabeth L. Eisenstein, 'The Early Printer as a “Renaissance man', Printing History, 3 (1981), pp. 6-16. 


\section{The Importance of Staying Connected}

In Poland-Lithuania, Januszowski was not 'the average small printer, who could not make the contacts that won wealthy patrons' ${ }^{8}$ Both printed books and archival documents demonstrate the support Januszowski received from lay and ecclesiastical dignitaries, with whom he had first made acquaintance in Vienna, in Padua, in the chancellery, or at court. There is not enough space here to mention all the names and elaborate on the nature and results of Januszowski's connection with them..$^{9}$ Suffice to say that the printer's main patron was Jan Zamoyski (1542-1605), who was the most powerful man in the Polish-Lithuanian Commonwealth at the time of Batory's reign. Zamoyski held two of the most important state offices: he was both Grand Chancellor of the Crown (that is of Poland, as Lithuania had its own chancellors and army commanders) and Commander-in-Chief. He had forged a spectacular political career as Batory's most trusted advisor. Even if it was the king who distributed grants, to obtain the royal favour one needed a proper recommendation and the support of a person who had direct access to the monarch..$^{10}$ In the 1570 os and 1580 os, the person closest to the king was Jan Zamoyski, who controlled the internal affairs of the Polish-Lithuanian Commonwealth and dominated Stefan Batory's patronage policy.

As early as 1578 , Zamoyski had seen to it that Januszowski was granted a privilege that made him a servant of the king (servitor), and a royal printer. ${ }^{11}$ This act had important practical implications, as it excluded the printer from any municipal jurisdiction, reserving law enforcement for the king. The same privilege gave Januszowski the sole right to print all books he chose to produce for ten years and banned his competitors from copying his imprints. The document also confirmed Januszowski's right to reprint works once produced by his

Robert M. Kingdon, 'Patronage, Piety, and Printing in Sixteenth-Century Europe', in Robert M. Kingdon, Church and Society in Reformation Europe (London: Variorum Reprints, 1985), p. 31 .

9 Kiliańczyk-Zięba, Czcionka i piórem, pp. 19-24; pp. 70-74.

10 Wojciech Tygielski, 'A faction which could not loose', in Antoni Mączak (ed.), Klientelsysteme im Europa der Frühen Neuzeit (Munich: R. Oldenburg Verlag, 1988), pp. 177-201, here pp. 192-193. See as well: Wojciech Tygielski, Politics of patronage in Renaissance Poland: chancellor Jan Zamoyski, his supporters and the political map of Poland, 1572-1605, transl. Paweł T. Dobrowolski (Warsaw: Wydawnictwa Uniwersytetu Warszawskiego 199o), a shortened version of a monograph published by the same author as Listy, ludzie, wtadza. Patronat Jana Zamoyskiego w świetle korespondencji (Warsaw: Viator, 2007).

11 Maria Juda (ed.), Privilegia Typographica Polonorum. Polskie przywileje drukarskie 14931793 (Lublin: Wydawnictwo UMCS, 2010), nr. 54. 
father, Łazarz Andrysowic (unless they were deemed heretical). ${ }^{12}$ Januszowski set about printing some of the titles explicitly mentioned in the privilege immediately. Other books listed in the document were potential ideas for future publication, and would not be printed until decades later. For example, Icones regum et principum Poloniae mentioned in the 1578 privilege, was only published in 1605 as Ikones książą i królów polskich.

Unfortunately for Januszowski, his 1578 privilege was not a permanent arrangement for treasury-sponsored editions. These (from 1577) were reserved for another Krakow printer favoured by Zamoyski, Mikołaj Szarfenberger, who was authorised to produce constitutions, the king's ordinances, decrees and law collections..$^{13}$ Nevertheless, in subsequent years Januszowski's acquaintance with the elite active at the royal court certainly helped him obtain commissions for a number of state-sponsored books. These included both large folio volumes like De verae et falsae Ecclesiae discriminae by Batory's court preacher Stanisław Sokołowski (1537-1593), as well as smaller books like Disputatio de putredine by the king's physician Simon Simoni $\left(153^{2-1602}\right) \cdot{ }^{14}$ It is relatively easy to trace the financial support of the king through the presence of a traditional formula on the book itself (such as 'sumptu et impensa regia' on the title page of Sokołowski's work).

Sometimes, though - and it is difficult to say how often and why - a royal commission to publish a particular title was not mentioned in the printed volume. That this must have been the case is suggested in editions like Iudicium de libro quem Lutherani vocant concordiae by Roberto Bellarmino, issued by Drukarnia Łazarzowa in 1586.15 The king's commission and the monarch paying for production is not indicated as such in the volume. Instead, it is attested by archival documents: first by a letter from Stefan Batory where the king commissions Januszowski to print 'librum patris Bellarmini' and to send him 200 copies, second by a receipt issued by Januszowski confirming that he has received the money to produce the book. ${ }^{16}$

12 Jan Ptaśnik, Monumenta Poloniae typographica (Lviv: Ossolineum, 1922), pp. 147-148; Juda, Privilegia, pp. 10-11.

13 Alodia Kawecka-Gryczowa and Anna Mańkowska, 'Szarfenberger Mikołaj', in Drukarze 1, 1, pp. 264-283.

14 Stanisław Sokołowski, De verae et falsae Ecclesiae discriminae (Krakow: Drukarnia Łazarzowa, 1583) USTC 242453; Simon Simoni, Disputatio de putredine (Krakow: Drukarnia Łazarzowa, 1583) USTC 242491.

15 Roberto Bellarmino, Iudicium de libro quem Lutherani vocant concordiae (Krakow: Drukarnia Łazarzowa, 1586) USTC 242586.

16 On the 12 of July 1586 Batory wrote from Grodno in today's Belarus to the treasurer Hiacynt Młodziejowski: "librum patris Bellarmini, quem volumus, ut istic Cracoviae elegantioribus typis excudi curet, nobisque 200 exemplaria mittat. Qua de re transiget cum Januszewski 


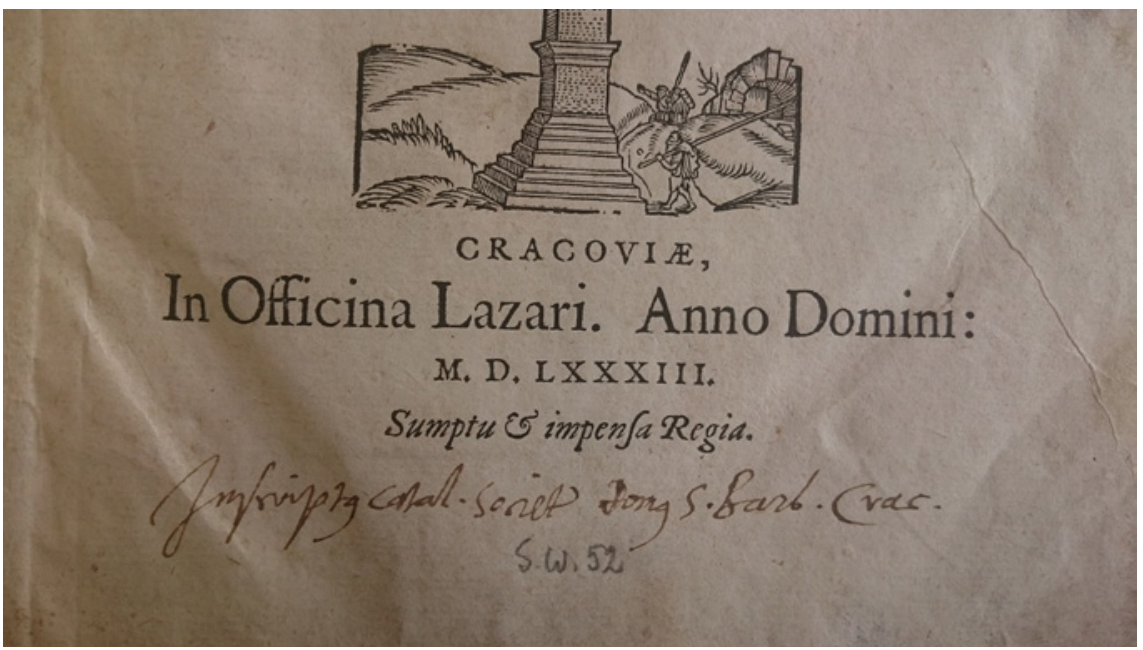

FIGURE 9.1 Stanisław Sokołowski, De verae et falsae Ecclesiae discriminae (Kraków: Drukarnia Łazarzowa, 1583)

\section{Close to the Church and Its Reformed Books}

Januszowski was unable to break Szarfenberger's monopoly on state subsidized editions, and treasury sponsored books remained only occasional projects for his workshop. ${ }^{17}$ However, he had a good understanding of the opportunities that printing books on the commission of the church authorities could give him. Naturally, he issued books authored or financed (or both) by local ecclesiasts. ${ }^{18}$ To boost the sale of these books he advertised that these were recommended by high-ranking prelates. For example, when a volume of catholic sermons Postilla ortodoxa by Marcin Białobrzeski (ca. 1530-1586) produced in 1581 proved slow to sell, he had the first sheet of the copies still in stock replaced by a newly printed one that contained mandates by Piotr Myszkowski (ca. 1510-1591), the Bishop of Krakow, and Stanisław Karnkowski (1520-16o3),

typographo" (Ptaśnik, Monumenta, pp. 361). On 9 September 1586 Januszowski confirmed that he had received the money from the officials of the treasury as was ordered by Młodziejowski (Ptaśnik, Monumenta, p. 361).

17 Kawecka-Gryczowa, 'Januszowski Jan', p. 79.

18 For example, a series of books printed in Drukarnia Łazarzowa was published by Stanisław Karnkowski, the prelate of Poland (e. g. Powinność chrześcijańska of 1582, whereabout of a copy once kept in the National Library in Warsaw are unknown; Hanibale Roselli, Pymander, libri III, IV and v of 1584-1586). 
the Archbishop of Gniezno, who both ordered their priests to improve their preaching with the use of the sermon collection printed by Januszowski. ${ }^{19}$

Januszowski was also appreciative of the opportunities offered by having a share in the printing of newly reformed liturgical books - volumes revised following the recommendations of the Council of Trent (held between 1545 and 1563). The period after the Council of Trent was crucial for the romanising of the Western liturgy, even if this process had been continuous from the twelfth century onwards. The Council recommended the unification of the liturgy, a revision of liturgical books according to Roman use, and finally the universal adoption of the Tridentine books. ${ }^{20}$ The reform of liturgical books and other Catholic texts was still underway when the Council ended. The new breviary was promulgated in 1566 , and the missal in 1570 . Other texts, such as a catechism and book of hours, had also been revised. ${ }^{21}$ The uniform imposition of the Roman liturgy by the local churches was possible thanks to the medium the Catholic reformers had at their disposal - the printed book. The Church authorities in Rome sought to control and supervise the production and distribution of revised texts. They required that the clergy and the faithful could only use the new, approved versions, and they granted privileges to print the reformed texts to chosen printers. For the printers who obtained such monopolistic privileges, this meant producing thousands of copies of texts in huge demand, as well as a predictable, substantial profit. ${ }^{22}$ Thus, Januszowski used his connections with local ecclesiastics to obtain the rights and commissions

19 Privilegia, pp. 92-94. The additional sheet contained as well letters from King Stefan Batory and Queen Anna Jagiellon to the author; both thanked Białobrzeski for copies received. See Magdalena Komorowska, "Large Volumes Bought by the Few": Printing and Selling Postils in Early Modern Poland', in Shanti Graheli (ed.) Buying and Selling. The Business of Books in Early Modern Period (Leiden: Brill, 2019), pp. 241-242.

20 Pierre-Marie Gy, 'L'Unification liturgique de l'Occident et de la liturgie de la Curie Romaine', Revue des sciences philosophiques et théologiques, 59 (1975), pp. 6o1-612. Liturgical matters, and in particular the reform of the breviary and missal were dis-

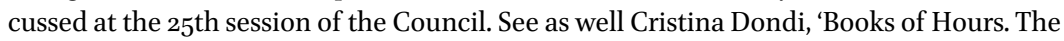
Development of the texts in printed form', in Kristian Jensen (ed.), Incunabula and their Readers, (London: British Library, 2003), pp. 56-57.

21 For an overview of the process see e.g. Niels Kroogh Rasmussen, 'Liturgy and Liturgical Arts', in John W. O'Malley (ed.), Catholicism in Early Modern History: A Guide to Research (St. Louis: Center for Reformation Research, 1988), pp. 273-297; Karen Lee Bowen, Christopher Plantin's Book of Hours. Illustration and Production (Nieuwkoop: De Graaf, 1997), pp. 63-64, Robert M. Kingdon, 'The Plantin breviaries: a case study in the sixteenth-century business operations of a publishing house', in Kingdon, Church and Society, pp. 133-150. 
to produce new liturgical books for the Polish-Lithuanian Commonwealth - a potentially very lucrative business.

The favoured printers for the task - most notably Christophe Plantin - were chosen early on..$^{23}$ Naturally Januszowski did not hope to compete with any of them, but to win the privilege to produce distinct versions of the new service books specially modified for Polish use. This was an achievable goal, since in their quest for the unification of the liturgy, the Catholic reformers had realised that local traditions were strong in many regions. For this very reason, Pius v made it possible for dioceses that had had their own liturgical books for longer than 200 hundred years to continue performing their rituals according to local rites. This was the case in the earliest Polish dioceses, where both manuscript and printed books reflected long-existing and highly-developed local traditions. The bishops, the synods and the specialists who debated liturgical matters at the time opted for the adoption of the Roman use, but with respect for the particularities of the ecclesiastical provinces in Poland. ${ }^{24}$ This attitude naturally implied that the respective volumes should be edited and then printed.

In the Polish Kingdom, the most energetic reformer of the liturgy in the Catholic Church was undoubtedly Marcin Kromer (1512-1589), the Bishop of Warmia. Kromer inspired and co-authored Agenda sacramentalia (1574) and Agenda ceremonialia (1578), which combined both the recommendations of the Council of Trent and local rites. ${ }^{25}$ These books were acclaimed by Polish bishops and used widely in the ecclesiastical province of Gniezno. ${ }^{26}$ Subsequently, Kromer published a breviary (1581), and made his assistants work on a missal that would conform to both local traditions and the standards of the Roman Curia. ${ }^{27}$ At the same time, at the beginning of the 1580 s, the archbishop of

23 Léon Voet, The Golden Compasses. A History and Evaluation of the Printing and Publishing Activities of the Officina Plantiniana at Antwerp, vol. 1: Christophe Plantin and the Moretuses. Their lives and their world (Amsterdam: Vangendt \& Co, 1969), pp. 65-70.

24 Paweł Sczaniecki, Stużba Boża w dawnej Polsce. Studia o Mszy świętej, seria druga (Poznań: Księgarnia św. Wojciecha 1966), pp. 142-145.

25 Agenda sacramentalia (Cologne: Maternus Cholinus, 1574) USTC 6o9588; Agenda ceremonialia (Cologne: Maternus Cholinus, 1578) Ustc 6o9575.

26 Władysław Nowak, 'Geneza Agendy biskupa Marcina Kromera', Studia Warmińskie, 6 (1969), pp. 173-209.

27 Breviarium Varmiense (Cologne: Maternus Cholinus, 1581), not in Ustc. Only three surviving copies, kept in the following libraries: Biblioteka Instytutu Północnego, Olsztyn, Linköpings Stadsbibliotek and Uppsala Universitetsbibliotek. 
Gniezno, the primate of Poland, Stanisław Karnkowski, chose a group of liturgists to edit a missal for the whole of his province. ${ }^{28}$

It is difficult to say when Januszowski started to establish contact with people who could commission the further production of Polish liturgical books in Krakow, using his printing shop rather than having them printed in Cologne. The earliest trace of such efforts comes from 1582, in a letter from Tomasz Płaza (ca 1512/1530-1593), a parish priest in Krakow, who had assisted Kromer's various ventures since the 155 os and was the bishop's trusted factotum. ${ }^{29}$ Acting as the prelate's representative, Płaza managed and supervised the printing of Kromer's works in Germany and elsewhere. He described his dealings on behalf of the bishop in informative letters sent to the prelate, of which over 250 are known to have survived until the present day. ${ }^{30}$ In 1582 , Płaza recommended Jan Januszowski to Kromer, saying that he is a good man and an exceptional printer'.31 In the same letter, Płaza informed Kromer that he had accompanied Januszowski to see the Archbishop Stanisław Karnkowski, the prelate of Poland, and that the printer was well prepared to produce liturgical books. Around the turn of the year, the idea to print liturgical books with Januszowski must have taken root among the dignitaries. Januszowski was promised the commission to produce breviaries and missals for the ecclesiastical provinces of Gniezno and Lviv with the financial support of the bishops. ${ }^{32}$ In May 1583, the King, Stefan Batory, signed a privilege reserving to Januszowski the right to print the reformed missals and breviaries aimed at Polish-Lithuanian dioceses and to sell them throughout the Commonwealth. ${ }^{33}$ Januszowski energetically prepared his workshop for the anticipated enterprise. In the same year, 1583, he took out a loan from Andrzej Patrycy Nidecki (1522-1587), a Krakow cathedral canon, and it is quite probable that he invested the money mostly in the founts

28 Władysław Nowak, 'Biskup Marcin Kromer jako liturgista', in Stanisław Achremczyk (ed.), Marcin Kromer i jego czasy (1512-1589) (Olsztyn: Ośrodek Badań Naukowych im. Wojciecha Kętrzyńskiego, 2012), pp. 174-176 (the same text published in Komunikaty Warmińsko-Mazurskie, 212 (2012), pp. 571-594).

29 Wacław Urban, 'Płaza Tomasz', in Polski Stownik Biograficzny, vol. 26 (Wrocław: Ossolineum, 1981), pp. 778-780; Janusz Małłek, 'Wstęp', in Marcin Kromer, Historyja prawdziwa o przygodzie żatosnej ksiażęcia finlandzkiego Jana i królewny polskiej Katarzyny (Olsztyn: Pojezierze, 1974), pp. XIII-XV.

$30 \quad$ Krystyna Stasiewicz, 'Korespondencja Tomasza Płazy z Marcinem Kromerem', Odrodzenie $i$ Reformacja w Polsce, 33 (1978), pp. 167-185.

31 "Jest dobry człowiek i typograf osobliwy". See letter by Tomasz Płaza to Marcin Kromer on 6 November 1582. AAWO, call no AB D 35, f. 52 v.

32 Stanisław Bodniak, 'W oficynie „architypografa”. Rzecz o kłopotach Januszowskiego', Silva Rerum, 5 (1930), pp. 138-143, here p. 139.

Privilegia, pp. 97-98. 
of roman type as well as musical types, with which he planned to print the liturgical volumes. ${ }^{34}$

However, his business became complicated. The prelates who had previously declared that they would edit the missal and the breviary for PolandLithuania and have it printed with Januszowski did not proceed with the work. Correspondence between all the involved parties suggests that Stanisław Karnkowski, the primate of Poland, hesitated to take the initiative and financial responsibility. ${ }^{35}$ Instead, Karnkowski proposed that the council of Poland (synod) decide about the production of breviaries and missals for the province of Gniezno. The bishop of Krakow Piotr Myszkowski (ca. 1510-1591) procrastinated, and asked the canons of Krakow cathedral to resolve the matter themselves. ${ }^{36}$ The chapter did not want to act, and the canons sent letters to Karnkowski and other bishops urging them to decide about the printing.

While waiting for the missal and the breviary for Poland-Lithuania to be edited and submitted to him, Januszowski used his connections in the circle of Catholic reformers to keep his presses busy. In 1584, he signed a contract to produce an Agenda for the Moravian diocese of Olomouc. The production was commissioned and paid for by Bishop Stanislav Pavlovský (ca. 1545-1598), a prelate of Silesian origin, whose links to Poland were particularly strong because of his diplomatic activities. ${ }^{37}$ Details concerning the production of the work have been preserved in documents compiled in the episcopal chancery. These sources inform us that the bishop's secretary, and one of the works' editors, Johannes Jerger, was sent with a manuscript copy of the book to Krakow two months before Christmas in 1584. The first part of Agenda (Agenda Sacramentalia) in 1,040 copies was ready within three months, and the second part (Agenda Cerimonialia) was issued in 6oo copies in 1586. Production costs amounted to over 2471 florins, including golden coins bearing Pavlovskýs coat

34 Kawecka-Gryczowa, Januszowski, p. 73.

35 Tomasz Płaza's letters to Marcin Kromer, Jan Januszowski's letters to both the Warmia bishop and his secretary, epistolary exchange between the Krakow Bishop Piotr Myszkowski and the canons of the Krakow Cathedral.

36 Letter by Piotr Myszkowski to Krakow Cathedral Chapter on 30 August 1583, Archiwum Kapituły Krakowskiej w Krakowie, call no LA 24, f. 227r.

37 See Jaroslav Pánek, 'Biskup Stanisław II Pawłowski, Polacy i Czesi (Prałat, polityk i mecenas pośrednikiem pomiędzy dwoma sąsiednimi narodami)', in Henryk Gmiterek and Wojciech Iwańczak (eds.), Polacy w Czechach, Czesi w Polsce: X-XVIII wiek (Lublin: Wydawnictwo UMCS 2004), pp. 89-101;Jakubec Ondřej (ed.), Stanislav Pavlovskýz Pavlovic (1579-1598). Biskup a mecenáš umírajícího věku (Olomouc: Muzeum umění, 2009). 
of arms, which were gifts received by Januszowski for himself, his wife and their three sons. ${ }^{38}$

In printing the Agenda, Januszowski could use the typographical and woodcut material that he had acquired to print the missals and breviaries for Poland-Lithuania. He also experimented with the visual appearance of the volume, for example by abandoning black letter for roman and italic characters. These typographical solutions recurred in the next liturgical volume Drukarnia Łazarzowa issued: Missale Varmiense. ${ }^{39}$

\section{The Missal and Its Patrons}

Missale was a commission by Marcin Kromer, the Bishop of Warmia. The plan for Januszowski to print liturgical books for the Commonwealth was devised around 1582. At the beginning, and even up to the early months of 1586, Januszowski and his protectors hoped that the printer would work on the missal for all the dioceses under Gniezno's jurisdiction and the missal for Warmia, an autonomous bishopric, at the same time. The plan was to have the larger part of the text in the missals to be identical, which meant that the production costs could be shared by the bishops, making the whole enterprise less expensive for the ecclesiasts and more profitable for the printer. Kromer had already proceeded in a similar way when he had produced his liturgical books in Cologne. ${ }^{40}$ However, Kromer grew rightly impatient with the other Polish bishops and with the primate Stanisław Karnkowski for delaying their decisions, and he eventually commissioned Missale Varmiense independently with Januszowski. ${ }^{41}$

The history of this publishing venture can be reconstructed thanks to surviving archival documents, mainly the letters Bishop Kromer received from Tomasz Płaza, his long-time assistant. Kromer resided in Warmia and Płaza

38 Ladislav Zavadil, 'Die alte Olmützer Agenda vom Bischof Stanislaus', Zentralblatt Für Bibliothekswesen, 1889, pp. 452-455; Karl Lechner, 'Nachtrag zur Olmützer Agenda des Bischofs Stanislaus Pawlowsky', Zentralblatt Für Bibliothekswesen, 1897, pp. 175-179.

39 Missale Varmiense diligenter recognitum et correctum (Krakow: Drukarnia Łazarzowa, 1587) Ustc 240295 .

$40 \quad$ Nowak, Geneza, pp. 200-205.

41 He was empowered to do so, as his diocese, that formerly belonged to the Riga ecclesiastical province, after its decomposition was a subject to Rome only and not to the archbishop of Gniezno. See: Wiesław Müller, 'Struktura organizacyjna diecezji rzymskokatolickich w Polsce w XVI-XVIII wieku', in Marian Rechowicz and Zygmunt Sułowski (eds.), Księga tysiaclecia katolicyzmu w Polsce (Lublin: Wydawnictwo Towarzystwa Naukowego KUL, 1969), p. 95 . 
lived in Krakow. It was Płaza who recommended Januszowski to the bishop and later on managed Missale Varmiense's production and distribution, regularly reporting to Kromer about the process. A handful of letters Januszowski wrote to Płaza and to Kromer, and those the Krakow Bishop Piotr Myszkowski addressed to his canons provides evidence for further developments. There is also a draft of a contract prepared by Januszowski, and a final agreement signed in 1586 by the printer, Płaza (acting as Kromer's proxy) and Marcin Glicjusz z Pilzna, canonicus Cracoviensis, who was a liturgist committed to the cause of post-Tridentine reform. Sources of secondary importance are a diary compiled in 1580 in Krakow by Maurycy Paweł Henik, Kromer's secretary, the Acta actorum of the Krakow cathedral chapter, a draft of Kromer's epistle to the Krakow canons, as well as Januszowski's letters to the chancellor Jan Zamoyski written in 1599, where the printer reminiscences about his enterprises from years earlier. Together, these documents give us an unusually detailed insight into how the production of Missale Varmiense was planned, organised and paid for. As such, they constitute the kind of evidence extremely rare for early printed books produced in Poland.

It was eventually decided that Januszowski would print Missale Varmiense in 1584. Almost a year later, in June 1585 , Płaza, acting as a middle man and the manager of the publishing process, reported to Kromer that he and Januszowski 'were ready for the missal', yet the bishop and his collaborators in Lidzbark Warmiński did not have a complete text to despatch to Krakow. ${ }^{42}$ While Płaza and the printer waited for the manuscript, they were planning the book's layout. Kromer was sent specimen pages of the envisaged edition and 'principum Agendae Olomucensis', certainly as proof of the Krakow workshop's technical abilities and the proposed design for the missal. ${ }^{43}$ At the same time, Płaza suggested that the bishop should have the missal printed with 'the bigger letter', which was more expensive, but 'more useful for old priests as well as young ones. ${ }^{4} 4 \mathrm{He}$ also revealed that the ultimate sources for the visual appearance of the planned missal were books produced in Antwerp, no doubt in Christoph Plantin's workshop. ${ }^{45}$ However, no contract was signed, perhaps

42 See letter by Tomasz Płaza to Marcin Kromer, June 1585, AAwo, call no AB D 35, f. 81r: "Typograf jest gotów do drukowania Mszału".

43 See letter by Tomasz Płaza to Marcin Kromer on 25 October 1584, AAwo, call no AB D 35, f. 73 r.

44 Letter by Tomasz Płaza to Marcin Kromer, June 1585, AAwo, call no AB D 35, f. 81r: "Będzie droższy egzemplarz niźli on mniejszym pismem, ale pożyteczniejszy kapłanom młodym i starym".

45 Letter by Tomasz Płaza to Marcin Kromer on 25 April 1586, AAWo, call no AB D 35, f. 9ov: "typis istis quorum exemplar mitto ad instar Antverpiensis imprimet missale". 
because Kromer, Płaza and Januszowski still hoped for the primate Karnkowski and other bishops to join them in the publishing enterprise.

Not only did this never happen, but the work of the trio was put to a halt by the Krakow cathedral chapter in the spring of 1586 . The canons declared they were afraid that the publishing of the missal might become a cause of papal disgrace, and warned Płaza and Januszowski not to begin printing without the consent of their general council held in May and until receiving a resolution of the Krakow Bishop Piotr Myszkowski. ${ }^{46}$ In letters he wrote in April 1586, an anxious Januszowski tried to persuade Płaza and his master, the bishop, to let him start the work 'when the day is long', if only by commissioning the paper for the edition. ${ }^{47}$ At the same time, Plaza reported to Kromer that he did not want the printer to go to any further expense 'because God knows if your highness will not change your mind and send the missal elsewhere or if the Krakow bishop will not forbid the printing. ${ }^{48}$ Kromer intervened with an irate letter to the canons. The Krakow ecclesiasts expressed their consent for the missal to be printed and the work continued. In June 1586, Płaza gave the printer the money to commission the paper for the volume. In August, a contract to print the book in 400 copies was signed (even if the printer consistently proposed producing 500). In the same month, Kromer received the first printed sheets of the missal. The work went swiftly, and the whole book was ready just after Christmas 1586, at the very beginning of January 1587 .

A wealth of epistolary evidence, along with the survival of secondary sources, reveals that the printing of Missale Varmiense was a cooperative venture: a multifaceted, dynamic process, spread over a period of about five years, hindered by the financial limitations of the commissioners, the ill will of the Church authorities, or even bad transport and weather conditions. More interestingly, since the documents that tell the story of how Misssale Varmiense was created are, for the most part, letters - ego-documents or Selbstzeugnisse - they reflect the human dimension of a printing and publishing enterprise. ${ }^{49}$ They give us

46 See letter by Tomasz Płaza to Marcin Kromer on 25 April 1586, AAwo, call no AB D 35, f. go- 91 r.

47 See Bodniak, 'W oficynie ...', p. 142; Justyna Kiliańczyk-Zięba and Katarzyna Gara, 'Listy Jana Januszowskiego do Marcina Kromera i Tomasza Płazy dotyczące produkcji Missale Varmiense (1587) w Drukarni Łazarzowej', Terminus, 20:3 (2018), pp. 383-401.

48 Letter by Tomasz Płaza to Marcin Kromer on 25 April 1586, AAwo, call no AB D 35, f. gor: "jeśli też vmcz nie odmienisz woli swojej a nie poślesz gdzie indzie, jeśli biskup nie dopuści drukować".

49 For the history and use of these terms see Michael Mascuch, Rudolf Dekker and Arianne Baggermann, 'Egodocuments and History: a Short Account of the Longue Durée', The Historian, (2016), pp. 11-56; Waldemar Chorążyczewski and Agnieszka Rosa, 'Egodokumenty - egodokumentalność - analiza egodokumentalna - spuścizna 


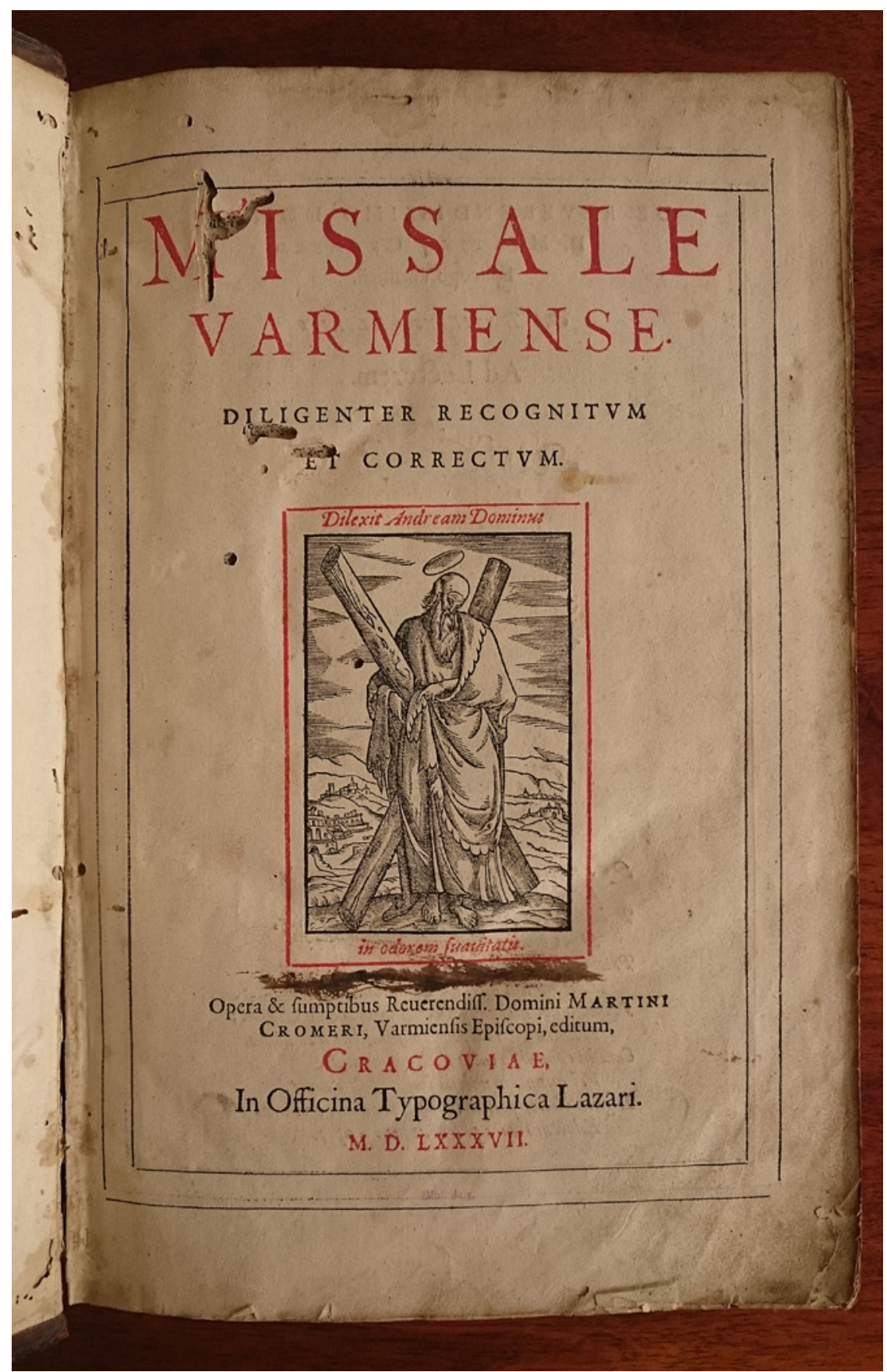

FIGURE 9.2 Marcin Kromer (ed.), Missale Varmiense diligenter recognitum et correctum (Kraków: Drukarnia Łazarzowa, 1587) 
a fairly good idea of the interactions among the people engaged in the process of printing a major volume: their ambitions, expectations, worries and joys. They expose the social relationships within the small group - personal, direct, and patron-client interactions. They leave no doubt that the social standing of Januszowski the printer was low compared not only with the bishop, whom he could only address in humble Latin supplications, but also in comparison with the other ecclestiasts he worked with. These were Tomasz Płaza - Kromer's factotum, and Marcin Glicjusz z Pilzna - the Krakow cathedral canon, who were both Januszowski's supporters in the period when he sought to secure a commission for printing liturgical books. Januszowski had neither power nor agency; the capital at his disposal was substantial enough to invest in new founts of type, but he would not commission the paper for the missal without money from his backers. Wealth, status and power were with Kromer; Płaza the bishop's middleman - emanated these qualities only thanks to his close relationship with the prelate.

Januszowski, the printer, and Płaza, who managed the publication process, worked under a lot of stress. They kept waiting and adapting. They waited for Kromer's decision on where to produce the missal. Then, they waited for the canons' of the Krakow cathedral and for Bishop Myszkowski's consent to begin the printing. They received the manuscript from Kromer in bits and pieces, and the money also came in piecemeal. The correspondence was irregular, and the recurrent rumours about Kromer's death caused additional stress. Płaza repeatedly rejoiced in his letters to Kromer that the bishop was still alive (Kromer eventually died in 1589). Finally, the letters reflect Januszowski and Płaza's pride in the results of their labours. Happy that Kromer was also content with the missal, his assistant wrote: 'these missals and your other books will commemorate you better than any rich property you could buy. ${ }^{50}$

Płaza, a local resident, spent a lot of time in Drukarnia Łazarzowa, correcting and revising text sent to Krakow by Kromer. In his personal letters to the bishop, Płaza praised the commitment and competence of the printer, and commented on the amount of labour Januszowski invested in the publication of Missale Varmiense. It seems that Januszowski was working to build his reputation as a specialist printer of liturgical books and perhaps, thanks to

egodokumentalna', in Waldemar Chorążyczewski, Arvydas Pacevičius and Stanisław Roszak (eds.) Egodokumenty. Tradycje historyczne i perspektywy badawcze (Toruń: Wydawnictwo Naukowe Uniwersytetu Mikołaja Kopernika, 2015), pp. 11-21.

50 See letter by Tomasz Płaza to Marcin Kromer. January 1587: AAwo, call no AB D 35, f. 85r: "więtszą pamiątkę vmcz tymi mszałami i inszymi księgami po sobie zostawisz, a niźlibyś kupił jakie bogate imienie". 
Kromer's recommendation, to attract the patronage of other prelates. However, Januszowski's apparent success with the Warmia missal and the satisfaction of his benefactors did not result in a Church commission to print the breviaries and missals for Poland-Lithuania with Drukarnia Łazarzowa. The sudden death of the printer's royal protector, Stefan Batory, and the turbulent time of the double election, which gave the Polish throne to both the Swedish prince Sigismund Vasa and archduke Maximilian of Habsburg, definitely discouraged the prelates, who were reluctant to invest in the production of the reformed liturgical volumes from the very beginning.

Januszowski, ever resilient, approached the bishops gathered in Warsaw in 1587 during the interregnum after Batory's death, and reminded them of the arrangements that had been made 'to print new missals and graduals for all Poland'.51 As late as 1589, the council of Poland (synod piotrkowski) confirmed Januszowski's privilege to print liturgical books for the Commonwealth. In October of the same year, Januszowski was paid in advance by the Bishop of Kujawy Hieronim Rozrażewski 'to print breviaries, missals and other liturgical books in his dioecesis.'52 In April 159o, King Zygmunt III Waza (Sigismund Vasa) recognised Januszowski's sole right to print all kinds of books needed by the clergy. ${ }^{53}$ Yet the results of Januszowski's negotiations with the episcopate must have been unsatisfactory; neither the missals nor the breviaries for the Commonwealth of Poland-Lithuania were ever printed in Drukarnia Łazarzowa in Krakow. Płaza was right when he reported to Kromer in May 1588, three months after the new King Zygmund III Waza was crowned in the Krakow cathedral: 'Januszowski, the printer, is angry with the bishops for having wronged him and failed with the missals. We will not see the missals for this province. ${ }^{54}$

51 Bodniak, Woficynie, pp. 140-141.

52 Paweł Sczaniecki, Stużba Boża w dawnej Polsce. Studia o Mszy świętej, seria druga (Poznań: Ksiegarnia Sw. Wojciecha, 1966), p. 146.

53 Januszowski obtained the right to print "libros usibus cleri necessarios, quos alioqui a peregrinis et remotis officinis typographicis petere cogebatur, utpote missalia, breviaria, agenda, antiphonaria, gradualia, psalteria et alia", Privilegia, nr. 73, pp. 102-104.

54 Letter by Tomasz Płaza to Marcin Kromer May 1587, AAwo, call no AB D 35, f. 133v: "Dominus Januszowski typographus rozgniewał się, iż go biskupi zawiedli i omylili z strony mszałów ... Nie doczekamy się mszałów pro hac provincia". 


\section{Conclusion: Complaints and Rewards}

Januszowski remained bitter about the failed venture for years to come, accusing the prelates of failing to honour their agreements. ${ }^{55}$ When Stefan Batory died and Jan Zamoyski fell out of favour with the new king, Januszowski complained about the lack of patrons who could provide the financial basis for much of the important publishing enterprises he wished to undertake: 'There is no patron, maecenas, promotor for me ... Eheu, fatum Janussovii!! ${ }^{66}$ Deciding to what extent his laments were sincere and justified still demands scholarly attention. After all,Januszowski obtained some reward for his labours on behalf of his highly placed backers. In 1590, he became 'architypographus regius and ecclesiasticus', a title that no doubt echoed Plantin's title. At the same time, a royal privilege reserved Januszowski the right to print both liturgical books and state publications. More importantly, two years earlier, in January 1588, the newly crowned King Zygmund III Waza, had elevated this craftsman's son to the nobility. In the 'gentry nation' that Poland was, this was an enormous social advancement, possible only for the most talented and conscientious and the best connected.

Throughout his career as a printer, Januszowski consciously emulated his successful colleagues active in most vibrant centres of print in Europe. Producing books for a provincial and an outlying market, Januszowski could not equal the enormous output of the most prosperous printers. Nevertheless his state and Church sponsored publications - Missale Varmiense in particular - exemplify well the potential of his workshop. At the same time the evidence provided by both the books printed by Januszowski and archival sources sheds important light on how an early printing office's fortunes related to or even depended upon patronage, support and sponsorship from those with wealth and power.

55 Letter by Jan Januszowski to Jan Zamoyski on 20 July 1599 quoted in Alodia KaweckaGryczowa, Z dziejów polskiej ksiażki w okresie Renesansu. Studia i materiaty (Wrocław: Ossolineum 1975), pp. 296-298.

$5^{6}$ Jan Januszowski "patrona, mecenasa i promotora nie masz.... Eheu, fatum Janussovii". See the letter by Jan Januszowski to Jan Zamoyski on 19 May 1599, quoted in KaweckaGryczowa, $Z$ dziejów, p. 3 oo. 